\title{
Community and inclusion: the impact of new communications technologies
}

\author{
LEE KOMITO \\ School of Information and Library Studies \\ University College Dublin
}

\begin{abstract}
Can new information and communications technologies increase citizen participation in civic life and promote community development? Worldwide studies of community information systems demonstrate that new technologies can enhance the effectiveness of activists. However, there has been little evidence that they bring in new participants. This article argues that e-government systems can, if properly designed and implemented, involve citizens who have not previously been active in local community life, and describes an Irish pilot project which has this capacity. The success of such systems depends not only on design issues, but also on the willingness of government to respond to the resulting policy inputs by citizens.
\end{abstract}

KEYWORDS community informatics, e-participation, e-democracy, Ireland, e-government, social capital

\section{Demise of community?}

Stories about the demise of community sometimes sound like the story of the boy who cried wolf, because it has been described as being under threat so often before (Wellman, 1988; Bell and Newby, 1971; Frankenberg, 1969). But, as with the story, perhaps this time the wolf has actually arrived. It is not necessary to debate distinctions between post-industrial, advanced industrial, and information societies (Robins and Webster, 1986, 1987) to accept that significant social changes have been taking place in recent decades. Industrial and post (or advanced) industrial growth has led to increased mobility from one locale to another, work and leisure activities taking place outside one's immediate locality, a decline in extended kin ties, and a declining concern with local area and reduced identification with local structures. If communities are defined by the traditional characteristics of longterm association of inhabitants, with multiplex, overlapping social ties amongst individual community members (Gluckman, 1971), whose interactions are based on trust and reciprocity (Polanyi, 1957; Sahlins, 1972; Mauss, 1967), the number 
of such communities is decreasing. Long-term residence is diminishing, the experience of working, living, and playing in the same physical space is less common for many people as individuals spend time outside their locality and associate with individuals who themselves have no other links in common. As segmented and fluid networks extending outside the locality proliferate, the locality becomes a 'washed out' version of community that is better described as a 'neighbourhood'. Of course, this is not a universal process and some localities can be aptly described as communities, but the trend is towards disengagement from locality as individuals' communication and information networks extend beyond locality.

This trend has attracted much social and policy comment, in Ireland and elsewhere. There is a perception that both civic and political participation in local communities is declining, linked with increased anti-social behaviour. This general decline has often been summarised as a decrease in 'social capital', a term made popular by Robert Putnam, and defined as stocks of social trust, norms, and networks which people can draw on to solve common problems (Putnam, Leonardi et al., 1993; Putnam, 2000). ${ }^{1}$ The civil decline is often also linked with a political decline, as evidenced by decreases in electoral voting and political activism (Blondel, Sinnott et al., 1998; Van der Eijk and Franklin, 1996). This has led to reactions from politicians, such as the announcement by the Irish Taoiseach (Prime Minister) of a consultation process on Active Citizenship, noting the need for 'public policy to facilitate and encourage a greater degree of engagement by citizens in all aspects of life and the growth and development of voluntary organisations as part of a strong civic culture'(Dáil Debates, Vol. 610 No. 1, Tuesday, 15 November 2005), ${ }^{2}$ as well as increased growth of research into the voluntary sector (for example the Third Sector Research Programme from the Royal Irish Academy).

There is often an uncertainty regarding the role of new information and communications technologies in this process of transformation (for a general discussion of ICTs and Ireland, see Komito, 2004). New technologies are enabling individuals to communicate with an increased range of other individuals and participate in a variety of new as well as traditional groups. Do new technologies contribute to a decline in individuals' participation in localities (Putnam, 2000; Nie, Hillygus et al., 2002; Nie, 2001), do they enable 'virtual communities' to flourish as alternative manifestations of traditional communities (Rheingold,1994; Etzioni, 2004), or can they reinvigorate localities by increasing the amount of participation (Tsagarousianou, Tambini et al., 1998; Hampton and Wellman, 2000; McQuillan, 2000)? More specifically, to what extent can new technologies increase the number of people who participate in activities and groups in their own locality? This article will focus on the support by governments of electronic technologies that can increase the number of people who participate in their local areas. First, the limitations of 'virtual communities' as replacements for local communities will be discussed. Evidence suggests that groups whose members communicate only electronically lack some of the features that characterise local communities. Then, the impact of new technologies on citizens' participation in local communities will 
be reviewed. There is evidence from throughout the world that new technologies intensify existing contacts within localities, especially by those already active in their localities. However, if the goal is to increase the number of people who get involved, there is less evidence that new technologies can provide this benefit. Through what government policy initiatives can new technologies encourage more people to participate in their locality? It is suggested that e-government projects might be structured in order to also increase civic participation, and a current Irish government initiative (Mohbaile), which combines e-government and e-participation, is described. The need for government support for such initiatives, and the problems that result from a lack of such support, is linked with the relative lack of impact of Mobhaile over a two year pilot period.

\section{Electronic communities: trust and reputation}

It is well accepted that new technologies are increasing the amount of communication between people separated by physical distances (Boase, Horrigan et al., 2006; Wellman, Quan-Haase et al., 2003). However, there is disagreement about which, if any, aspects of proximate community can transfer into electronic or virtual communities. The kinds of social groups which emerge from such communication are varying. One, for instance, would be communities of interest: individuals who share a common work or recreational interest and share information and advice amongst participants. There are those who have a commitment to shared aims or goals (such as anti-globalisation movements) and work together to achieve that shared purpose. There are also Diaspora communities: people who associate with non-local expatriates; they feel solidarity through participation in home culture when abroad, and offer mutual assistance and well as sharing of experiences. Participants in such groups often 'feel at home' or 'feel normal' through such participation.

It is sometimes argued that electronic communities lack crucial characteristics of traditional communities, and 'virtual communities' would be better described as simulated or ersatz communities (see Komito, 1998, 2001 for a fuller discussion of this virtual communities debate). There is at least one characteristic of local physical communities that is often not replicated in an electronic environment and which has important implications for civic participation: involuntary interdependence. Local communities are composed of relations of reciprocity and exchange - people helping each other, without looking for immediate return, but expecting that reciprocal assistance would be provided at a future date, if necessary. This generalised reciprocity was identified many years ago by Sahlins (1972) as a feature of non-industrial societies, and follows from Polyani's (1957) discussions of economics embedded in social relations. Generalised reciprocity is supported by the glue of dense social networks; individual's violation of norms does not remain private but becomes part of the individual's public reputation and can be punished by a broad range of sanctions, both social and economic in nature (for a discussion 
of social networks see Mitchell,1969; Banton, 1968; Holland and Leinhardt,1979; Berkowitz, 1982; Wellman and Berkowitz, 1988; Wasserman and Faust, 1994; Smith and Kollock, 1999). The trust that underpins generalised reciprocity is built on this. Individuals who do not honour this informal rule will lose their reputation, no one in the community will risk trusting them, and so they will be excluded from claiming assistance they might need in the future. Therefore, generalised reciprocity involves little risk; people involved in these reciprocal relations may not even like each other, but they still know that a concern with reputation will ensure compliance.

Membership in electronic communities is often, by virtue of the very nature of such communities, voluntary, and people can simply opt out of a group, at no cost to themselves by not engaging in communication. Once individuals have the option to cease participation in a group, this makes it much more difficult to enforce norms. Generalised reciprocity depends on trust - trust that other people will abide by the rules and eventually 'do unto you' as you did unto them, but when members can avoid obligations simply by leaving, where then trust and reciprocity? Voluntary groups can depend only on the benefits that individuals derive from continued membership to encourage commitment to the group and appropriate behaviour. There are numerous cases when this works; there are many accounts of shared experiences such as illness or collective commitment to a common purpose creating strong group identification, and this ensures reciprocity and adherence to rules (see Kollock, 1999 for such examples). However, individuals' continued commitment cannot be compelled and people can simply lose interest or no longer obtain sufficient benefit from membership to warrant continued participation. For this reason, nurturing virtual communities is a delicate process, and rules of thumb for such groups abound. ${ }^{3}$ The problem exists for all voluntary groups, including groups whose members meet face-to-face, but research suggests that voluntary electronic groups are more vulnerable to this problem than voluntary face-to-face groups (Kolko and Reid, 1998; Watson, 1997; see also Kitchin, 1998: 86-90). As a result, the social impact of electronic communication is not electronic groups which replicate traditional communities but, to use Wellman's phrase, 'networked individualism' (Wellman, Quan-Haase et al., 2003): the proliferation of weak ties of acquaintance, linking individuals geographically distant from each other, but with a decrease in dense overlapping networks. The resulting electronic groups are permeable, with fluid memberships and amorphous boundaries and are imperfect replacements for local communities.

\section{ICTs and e-participation/inclusion}

Electronic groups may be unstable, but electronic interactions are significant elements of social groups nonetheless. The growth of 'social networking' sites such as MySpace, Friendster, Facebook, and Bebo indicates the power of electronic interactions. ${ }^{4}$ However, these electronic interactions often reinforce the 
face-to-face interactions of individuals who already share the same physical space. This impact of new technologies is not restricted to teens and 'twenty somethings' who use email and share photos with school friends. Wellman (1996) has shown that, even if local ties do not necessarily constitute a significant percentage of existing ties of emotional attachment and mutual assistance, local interactions still constitute a significant percentage of daily contacts for most people. Furthermore, a large number of electronic communications are with people who live locally. The Netville study (Hampton and Wellman, 2002) described a community in which a significant number of households have Internet access; those who use the Internet have more contact with local residents that those without Internet access. Kavanaugh et al. (2003) found the same in their Blacksburg project. Not only do individuals have email contact with those geographically proximate to them, but such individuals also report increased face-to-face and phone contact as well (Boase, Horrigan et al., 2006). Thus, new technologies can intensify the amount of interaction amongst people who live in the same locality.

It is also clear that new technologies increase levels of activity within, and the effectiveness of, voluntary/community groups. In societies where the barriers of access have been lowered (e.g., United States, Canada, Western European, Japan, Korea, and so on), there has been a proliferation of local organisations (sports, culture, church) with web pages, discussion lists, bulletin boards, and so on (for example, in Ireland http://www.ennis.ie hosts many local voluntary groups, see McQuillan, 2002; as well as O'Donnell, Trench et al., 1998 for other examples; for the United States, see PEW Internet and American Life Project 2001). Membership matters are dealt with via email, events are announced, issues are discussed, and so on.

While new technologies assist voluntary groups to carry on their activities, the evidence that new technologies increase amounts of community participation is less clear. In most discussions of e-participation/inclusion and general debates (including policy debates) about social capital, the issue is not enhancing the effectiveness and amount of interaction of those already involved in community initiatives - the issue is how to encourage participation by citizens not previously active in local communities and groups. Although some anecdotal evidence suggests ease of access to the Internet increases levels of local participation (e.g., McQuillan, 2000 on experiences in Ennis, Ireland), detailed empirical surveys are more ambiguous on the issue (Kavanaugh and Patterson, 2002; Pigg and Crank, 2004). There has been conflicting evidence, and conflicting interpretations of the same evidence, about the impact of new technologies on public participation in civil society (Wellman and Haythornthwaite, 2002; Huysman, Wenger et al., 2003), and the extent to which government sponsored programmes can increase levels of participation.

As noted, research suggests that the people who use new technologies for community policy issues tend to be people who are already activists - those who already 'network' (in social capital parlance, those who have bridging links based 
on weak or thin network ties) use new technologies to network more effectively (Kavanaugh, Reese et al., 2003; Agre, 2002; (see O’Donnell and Ramaioli, 2004 for an Irish example of new technologies linking voluntary groups)). One of the earliest experiments in the use of technologies to enhance public participation at local level was in Santa Monica in 1989 (Docter and Dutton, 1998), and it was one of a number of experiments in community building using new technologies (Tsagarousianou, Tambini et al., 1998). The evidence from such projects has not been encouraging.

Governments are also trying to increase public participation in politics and policy. These projects have sometimes been described as 'e-participation' or 'e-inclusion', and have included online forums, virtual discussion rooms, electronic polls and electronic voting (Organisation for Economic Co-operation and Development 2003). The projects seek to improve public participation in policy making, but most such projects are 'trials' and there has been little evidence that these projects have increased civil participation in the long-term (O'Donnell, 2001).

Lack of participation has sometimes been blamed on the 'digital divide': individuals are excluded from participation because they can not afford access to the necessary technologies or do not have the training or background to feel comfortable using them (McCaffrey 2003; Haase and Pratschke 2003; Lenhart, Horrigan et al. 2003; Sciadas 2002; Birdsall 2000). Certainly there are barriers to access, and free access via public libraries and other open access points does not remove these barriers. However, such barriers are diminishing over time (International Telecommunication Union and Minges 2003; National Telecommunications and Information Administration 2002), and yet there still remain a large number of citizens who are disengaged from the policy process and, indeed, from their community in general. Even when there has been access to technology and people can use the system, there have been relatively low levels of take-up, as a percentage of the overall target population. For instance, the winner of the Top 10 vote at the World Forum on e-Democracy in September 2005 was BBC's grassroots campaign website, Action Network ${ }^{5}$ (http://www.bbc.co.uk/ dna/actionnetwork/). Yet, there are only thirty-eight users listed for Canterbury, a town with a population of about forty-two thousand. Nor is it clear how governments plan to increase participation rates (e.g., O'Donnell, 2001 on European policies). A recent European Union policy document, 'The Role of eGovernment for Europe's Future' (Commission of the European Communities 2003), could only propose that all e-Government strategies should 'promote ... online democratic participation'.

An obvious explanation for low participation is the 'free-rider syndrome' (Olson 1965): citizens know that, even without their intervention or participation, appropriate decisions will be made and so they choose not to 'waste' their precious resources of time and effort on participation. Civil apathy may actually be costeffective: even if electronic systems are available, individuals may not derive sufficient benefit in civic participation to warrant investing even minimal time and 
effort (e.g., Arnold, Gibbs et al., 2003). This is especially pertinent when there is a low perception of 'efficacy' - why bother if one's efforts are going to have no impact? Such an explanation is relevant in Ireland, where a strong centralised government has constrained political and executive autonomy at the local level (Barrington, 1975; Roche, 1982). This, along with a view that personal connections determine local authority and national government outcomes, even for individual citizens, has been used to explain low levels of public participation in policy discussions and determinations.

Despite this 'free-rider' explanation for low participation, citizens actually do organise and participate if local issues arise about which they feel sufficiently strongly: planning, amenities, waste disposal, and so on. There is evidence in all parts of Ireland, as elsewhere, of individuals organising ad-hoc groups to exert policy pressures on single issues (e.g. waste charges, recycling, local planning, provision of local hospitals and health centres), and many of these groups use new technologies to provide internal organisation and communication functions that enhance their effectiveness (O'Donnell, Trench et al., 1998; as well as O'Donnell, McQuillan et al., 2003). However, once the issue, whether planning, waste disposal, or vandalism is solved, such groups tend to dissipate. Residents' groups, which develop to exert pressure on developers and local authorities to resolve outstanding issues in housing estates, tend to atrophy as housing estates mature and problems diminish. The policy aim must be to facilitate the continued existence of such groups, to maintain the involvement of people in such groups once the single issue that motivated action has been addressed, and to encourage greater public participation in such groups.

\section{Service provision and participation}

The benefit, in terms of social capital, from increased civic participation is the elaboration and maintenance of social networks within a locality. While the evidence from trials of new technologies have not, so far, been encouraging, new e-government initiatives provide an interesting opportunity. The Irish government, like other governments, has invested in e-government initiatives, resulting in a consistent increase in the use of new technologies by citizens to interact with the state (Central Statistics Office, 2003; 2006). From the perspective of local authorities, this enables them to provide services more efficiently, and it can also reduce their own costs. Not only can money be saved by getting citizens to fill in and submit their own forms and payments, but citizens can also provide monitoring functions that local authorities would normally have to pay for themselves. For example, citizens can report a service fault (e.g., faulty street light or abandoned car) by locating it on an electronic map, and communicating that information to the local authority. Such a service is obviously beneficial to the local authority, since it enables rapid notification of problems that need attention and at little cost to the authority. The local authority is, in effect, 'out-sourcing' the monitoring of service 
delivery and repair issues to its citizens, which reduces staff costs while also speeding up repair times.

Such a service could also encourage civic and voluntary participation in localities. Rothstein (2003) points out that trust is rarely given unconditionally, especially to governments composed of unknown and unaccountable individuals. Trust is earned, based on actual interactions that citizens have with particular agencies of the state. That trust, once gained, can be extended to other agencies of the state and thus transmuted into greater commitment to civil society. Individuals can learn that their participation in the administrative system, even if it is only through directly applying for, and then receiving, benefits to which they are entitled, works. This increases citizens' belief in accountability and influence over the administrative structure by providing convincing evidence that intervention has an impact, and individual intervention can be effective. It may also create a habit of participation and interaction, which can be transposed to the local community arena.

An example of a system with such potential is the Mobhaile ${ }^{6}$ project sponsored by the Irish government through the Local Government Computer Services Board (http://www.lgcsb.ie) which has been undergoing pilot testing in various local authorities throughout Ireland since 2004 (http://www.mobhaile.ie). It is a webbased portal that enables transactions in three domains: government services, business, and community/voluntary groups. Its strength is that local government bodies already hold data about their areas and the citizens and organisations in those areas. This data has to be kept up to date in order for the local authority to function, and can be made available to the general public through a web interface at little additional cost. Information about local services is presented in a geographical format, which makes it easy for individuals to access the information of relevance to their locality by simply clicking on the relevant street or area on a local map. It is possible to restrict information to the neighbourhood subset of services (for example, only garbage collection schedules, bus route timetables, planning submissions in that area), so that citizens are not overwhelmed with irrelevant information and only see information relevant to the local area. This fosters an awareness of a community as a geographical entity, as well as improving the efficiency of information retrieval. Since the system largely depends on capturing data that is already on internal administrative information systems, it is relatively inexpensive to deploy.

It can also provide an enhanced sense of accountability and participation for citizens. The Mobhaile geographical input/output format is linked with an openended web form so that when individuals pinpoint a location on a digital map, they can write a text about the problem - whether that problem is a broken street light, abandoned car, blocked drain, or any other issue which requires attention. ${ }^{7}$ The message is then dealt with by local authority officials, and the citizen receives a report. Thus, if one reason for low participation rates in perceived lack of efficacy, then this project alters that perception by providing citizens with evidence that 
their participation is effective. It may only be with regard to street lights or waste collection, but it demonstrates that citizen participation has an impact none the less.

In addition to central and local government services and benefits, the portal hosts community and voluntary groups, and local business organisations. Even those organisations which already host their own web sites or bulletin boards, can benefit from being registered: in addition to providing location information to portal users, businesses and groups can contribute announcements or descriptions about their activities that are viewed by anyone accessing the site. Once registered, groups have access to a targeted local audience, and can also be notified by the local authority of issues that affect their particular locality. Users may interact with the voluntary group or business (whether getting tickets for a concert or joining the group), register for notifications, and check for recent announcements. Groups can use the portal for a variety of internal functions, such as paying membership dues, and there is the potential for discussion boards and electronic mailing lists. Sharing documents between members, SMS messaging to members, receiving payments or subscriptions on line, and taking polls, are all potential functions that voluntary and community groups with a limited budget could not otherwise afford.

The information system also has a 'social networking' component that enables public sharing of information. For instance, individuals can create their own 'blogs' (web logs) and make them available to other members of the locality. The software is flexible, and enables the creation of forums or discussions groups on issues that concern citizens. The information system encourages increased voluntary participation, but also increased informal information exchanges and ad-hoc group formation. The latter is as important as the former in social capital formation and community building.

Such a system clearly reduces the cost of participation, and there is already strong evidence that individuals and groups use new technologies to facilitate exchange of information and coordination of activity on community issues. Politicians now send out newsletters electronically and receive queries from citizens via email. More significantly, there is evidence of new technologies being used for collective action. Residents and community groups use technology to organise their own activities and coordinate representations to politicians and officials. Officials now receive 'round robin' emails - a message will have been distributed to members of a residents' group or sports club and each will then send the message to local officials. While it is clear to officials that the message has simply been redirected, and a duplicated message has less impact on a local official than an equivalent number of individual and personalised messages, it still functions as a 'straw poll' of those who feel strongly enough about an issue to engage in some level of policy discussion. This is similar to findings from the Blacksburg, Virginia project, where activists increased both networking and social capital as a result of new technologies (Kavanaugh, Isenhour et al., 2005). New technologies increased levels of informal communication amongst individual activists and levels of 
information exchange between individuals and service providers. Such informal participation may be as significant as formal participation in terms of social capital, although such participation tends to be discounted due to problems of measurement (Newton, 1999).

\section{Participation versus consultation}

It is clear that new technologies are becoming part of the repertoire of many citizens. An example of interest in increased participation is the increasing number of telephone polls, in which radio or television listeners respond to a simple yes/no question by phoning or texting the appropriate number. This can provide a large number of responses in a very short time; in Ireland, some have had participation rates of over ten thousand phone calls. ${ }^{8}$ However, regardless how well an information system is designed, and regardless of the evidence exists that citizens are increasingly willing to use new technologies to convey their opinions to policy makers, neither will be sufficient to encourage participation unless the efficacy issue is also addressed. Macintosh (2004) has suggested three levels of electronic participation in policy making:

- information - unidirectional information flows, in which governments produce and deliver information for use by citizens

- consultation - citizens provide feedback on policy issues identified by government

- participation - citizens themselves partly define the process and content of policy making.

Many government projects provide information, but less often consult, and often discourage participation (O'Donnell, 2001). Yet, citizens need evidence that, when they attempt to influence policy, government listens to their input and the policy outcomes are altered. Research suggests that low participation rates are linked to citizens' perception that their participation has little impact (The Power Inquiry, 2006).

To be fair, public participation in policy is problematic. When citizens partly define the process and content of policy making, as well as alter policy outcomes, this raises problems of accountability and representation. In the absence of a plebiscite on every issue, to what extent are non-elected and voluntary participants representative of the diversity of interests and views in a community? Even more troubling, from a legal perspective, how can such participants be accountable for the future outcomes of their decisions? Officials in Irish local authorities are explicit in their belief that local activists may not be representative of community opinion. Officials fear that local activists have vested interests, and decisions could be determined by those interests who are most vociferous and best organised: decisions based on listening to those who shout loudest. ${ }^{9}$ Such activists come and 
go; it is the local authority which is legally held accountable for the consequences of policy outcomes.

Even if the community, as a whole, votes on an issue, there is still a potential conflict between the 'common good' versus the 'not in my back yard' approaches to policy. When an issue mobilises a large number of citizens, new technologies enable ad-hoc groups to organise effectively and quickly in order to exert pressure on local authorities. This 'swarming' effect is often effective, and local authorities respond to the demands. The problem, from the local authority's perspective is that, once the issue has been resolved, the mobilised citizens often fade into the background as the ad-hoc groups lose coherence. For many officials, retaining the right to decide how seriously to consider the input from 'participation' or 'consultation' is a legal necessity. Not only is it a means of ensuring that the wider community is not excluded from participation by unrepresentative activists, but it is also a means to ensure the wider public interest is also considered. The goal of local officials is that citizen participation will, through dialogue, lead to consensus agreement on contentious issues, but officials feel compelled to retain their authority as final arbitrators of the 'public interest'. ${ }^{10}$

\section{Citizen participation in Irish local authorities}

Given this background, what has the experience in Irish local authorities been, and how successful, in that context, has the Mobhaile project been since its inception in 2004? Regarding the former, the dialogue offered by Irish local authorities appears to be based on a restricted definition of consultation. An example of local authorities' 'consultation' was the 2003 controversy regarding a large residential plan for Adamstown in South County Dublin, which attracted significant local and national media attention. The controversy led to protests and meetings, as well as a substantial number of email messages to the County Council. Although there was no electronic bulletin board to facilitate discussion of the issue at that time, the concerns raised by individuals were addressed and responded to in the form of a series of Frequently Asked Questions (FAQs) which were available on the Council web site. Politicians and other interested parties checked the information and conveyed that information back to residents via public meetings or electronic mailings. One result was a dedicated web site (http://www.adamstown.ie/) on these issues. The County Council officials considered all input, including emails, seriously, but there was no provision for online discussion of the issues, nor any means by which citizens could redefine what constituted an issue. This ad-hoc interaction was 'consultation' in a rather limited fashion, since the local authority determined the issues about which it would seek citizen input, determined the scope of consultation, and reserved for itself the right to a final determination. ${ }^{11}$

Other Irish local authorities have followed similar strategies. Meath County Council, with regard to a contentious plan for a motorway near an archaeological site, launched a dedicated web site (http://www.m3motorway.ie/). There is much 
information on this site about how the route was chosen, the archaeological research being carried out, and a FAQ (Frequently Asked Questions) page with common issues. The aim of the site is to persuade as well as inform, but any impact on policy is limited to the traditional avenues of politicians and interest groups. Again, there is no mechanism by which citizens can contribute their opinions, or engage in an electronic dialogue with the local authority. Such dialogue is technically feasible; there has been an e-consultation research project (http://www.e-consultation.org/) funded as part of North-South government initiatives (North South Research Programme 2004 to aid Peace Process), in which various organisations, such as Waterways Ireland (http://www.waterwaysireland. org/), encouraged participation and discussion of issues and agendas by citizens. ${ }^{12}$ Furthermore, in 2006 the Irish Government and Oireachtas jointly initiated an innovative pilot project which enable electronic discussion by the public on proposed legislation, in which individuals and interest groups are not only able to influence what issues are defined as relevant, but also able to view, and comment on, the comments that others have made on those issues (see http://www. econsultation.ie). Clearly, any restriction on citizen participation is due to administrative policy, not technical limitations.

The evidence from the Mobhaile project is also not hopeful. The project has, over the last two years, had very little effect on linking e-government, community groups, and public participation. This has not been due to any lack of interest in the project by voluntary groups. Interviews with individuals involved in a number of the pilot local authorities indicated a positive response to some aspects of the Mobhaile project. Voluntary groups that were offered web sites responded positively; in many cases, they were attracted by inexpensive web hosting, free training in easy to use publication tools, and a reduced rate for having their own web address. One attraction of the Mobhaile project has been the facility to provide a web alias so that groups could have their own web address, providing an easy to remember 'brand' (e.g., www.group_name.ie). While a large number of voluntary groups who originally received training in web publishing have not maintained their web site, a significant number of groups maintain their web sites and report benefits from the sites. Community groups reported that emigrants were using the web site to keep in touch with home activities, and other voluntary groups felt that their web sites helped link them with voluntary groups with similar interests. There were several cases in which individuals set up websites as a means of getting a residents' association in their locality started. Sports groups appear particularly likely to maintain their web sites and receive frequent visitors to their site. Such groups have weekly announcements (e.g., where and when a match is to be played, as well as the subsequent match result) which makes the material central. Even groups whose web sites have a low level of activity are still positive about having a web site, all of which is similar to reports from research elsewhere (e.g, the Blacksburg project already discussed). 
However, the integration of voluntary activity with local e-government has not taken place. On Mobhaile sites, there are few easy links between e-government and voluntary groups or local services. Users of e-government services don't easily find community resources on the site, and many community web sites have no link with e-government. A number of explanations have been advanced for slow progress on the Mobhaile vision. There have been problems with software and hardware reliability, as well as a significant cost to local authorities if they use proprietary software. There have also been difficulties in adapting the software to take advantage of local information. However, such technical problems are capable of solution; there has been a general lack of political will, at both administrative and political levels, that such integration should take place. For instance, in one local authority, the section dealing with web sites for voluntary and community groups is not only separate from the section that deals with e-government issues (e.g., local amenity provision, bin collection, waste charges) but the two sections have no contact with each other and no knowledge of each others' projects.

In another local authority, where there is sufficient political and administrative will for such integration, the authority is developing its own software, independent of the Mobhaile project. While the project has the same aims, and a similar format, as the original Mobhaile project, the local authority is avoiding a dependence on proprietary software. Since the project only began in mid 2006, it will take a few years before it becomes clear whether integrating e-government service provision with voluntary groups and business will result in improved citizen participation. The very fact that a local authority had found it necessary to pursue an independent policy is further evidence of the slow progress of the Mobhaile project. Insufficient commitment from both local and national government is a barrier to integrating e-government and civic participation.

\section{Conclusion}

What, then, is the impact of new technologies on communities? Some have argued that geographically defined communities as repositories of identity and social cohesion are inevitably on the wane, but that the process has been accelerated by new technologies (Wellman, 1999; Castells, 1996). Instead, larger and geographically dispersed personal networks are emerging, composed of weak or 'thin' ties rather than personally significant ties (Boase, Horrigan et al.,2006; Wellman, Quan-Haase et al., 2003). However, new technologies are not restricted to communication with geographically distant individuals; evidence is clear that both strong and weak ties with individuals within localities are also maintained via new technologies. Social networking sites (e.g., bebo.com) demonstrate that new technologies can also amplify and intensify face-to-face social relations amongst individuals within localities, as well as support relationships across distances. In addition, new technologies have been beneficial for voluntary and community groups in localities, and research throughout the world indicates that new 
technologies enable activists to become more effective, and links between activists to increase as a result.

New technologies have not, however, had the effect of encouraging participation by individuals not already active in their locality. The reason why new technologies do not encourage more people to participate in their locality is not clear. In so far as individuals' lack of participation in local neighbourhoods is due to apathy ('free-rider syndrome') or perceived lack of efficacy, one solution is to 'piggy-back' on the increasing use of e-government services by citizens. Information systems like Mobhaile that combine e-government functions, along with community and voluntary group participation functions, enable citizens to explore electronic participation options when they use the e-government services. Since citizens are using e-government functions with increasing frequency, this encourages community participation as well.

Such systems may increase local participation, but only under certain conditions. Citizens' participation must have the capacity to alter policy outcomes, and must be seen to have that capacity. Otherwise, policy discussion is only a means by which the state can maintain public support without relinquishing its autonomy, and citizens, recognising that reality, will quickly abandon any interest in participation. Participation has to be supported by the state, and to be been seen as integral to government policy, as illustrated by the recent Irish government initiative on impending legislation (http://www.econsultation.ie/). If participation has policy consequences, then citizens are more likely to become involved, and then remain involved, as policy issues arise that concern them.

The Mobhaile project was intended to combine e-government with access to local voluntary groups, businesses, and amenities, but has so far had limited impact. One element of Mobhaile was the provision of web sites for local groups, and this facility has been popular (even though many sites are not kept current). However, even those groups who have found the web site facility beneficial report little significant increase in new participants. This may be because the links between e-government, voluntary groups and local services on Mobhaile sites are either non-existent or difficult to navigate. In general, users of e-government services don't easily see community resource links, and community web sites have no links with e-government. In many cases, when individuals access the community web sites via an 'alias', they bypass the Mobhaile site, and thus any local business or e-government links, completely. Furthermore, there has been no broad effort to encourage public participation in policy formation. Local authorities use their web sites to make information available, but not for feedback or discussion.

Many governments espouse 'e-participation' and 'e-inclusion' policies to address the issue of communities becoming neighbourhoods, as locality has a diminishing claim on individuals' loyalty and identity. However, a lack of effective support by local and national governments for technologies that encourage participation and inclusion hinders the success of such policies. This is not just a question of designing and deploying appropriate software, it is also a question of 
demonstrating that the use of such software has an impact on policy. Lack of efficacy and a consequent 'why bother' response is a significant issue. Evidence from Ireland suggests a lack of political and administrative will has created obstacles to participation, by not ensuring that solutions to technological impediments are found and by not demonstrating that citizen input has policy outcomes.

It remains unclear whether e-government projects can also encourage greater civic participation. However, despite formal policy statements from the Irish government, it is clear that, so far, there has been insufficient support for an integration of e-government and civic participation, and this lack of support makes increased participation unlikely. New technologies may, even without such intervention, support local civic involvement; activists will use any resources that are available, and new technologies provide many cost effective options. Voluntary and community groups will use new technologies to enhance their effectiveness but this does not radically increase the number of individuals who participate in their locality. If governments wish to encourage active participation by the wider community, then they have to provide greater incentives for citizens to participate. Without targeted initiatives, new technologies are unlikely to encourage participation by the great majority of non-involved citizens.

\section{Notes}

1 Though it must be emphasised that Putnam's views on social capital are by no means unproblematic (Farr 2004; Portes and Landolt 1996; Agre 2004; Farrell, this issue)

2 The Report of the Task Force on Active Citizenship was published in early 2007.

3 See, for instance, a set of rules by Mike Godwin titled 'Nine Principles for Making Virtual Communities Work', first published in 1994 in Wired magazine and available at http://www.wired.com/wired/archive/2.06/vc.principles.html.

4 For a recent report of US patterns, see a report from comScore Media Metrix that in February 2006, 16.9 million Americans visited at least one of four social networking sites (http://www.imediaconnection.com/content/5437.asp).

5 http://news.bbc.co.uk/go/rss///1/hi/technology/4298662.stm

6 The name Mobhaile derives from an Irish term which roughly translates as 'my community'.

7 In South County Dublin, for instance, citizens can report problems with road defects, pavement defects, pedestrian crossings, signs and street name plates, flooding, street lighting, bin litter, dogs, street cleaning, dead animals, fly posting, bus shelter / bus stop problems, graffiti, and abandoned vehicles.

8 The participants may be unrepresentative due to self-selection and may still only be a small percentage of the total population of more than four million people, but a sample size of ten thousand is still likely to have some predictive value. For instance, in April 2002, 72 per cent of the 8,430 participants were dissatisfied with the bishops' statement on clerical child sex abuse (The Irish Times, 10 April, 2002). In October 2003, three out of four of 16,000 participants agreed that residents should pay to have rubbish collected, which was during a high visibility protest over such charges (Sunday Independent, 19 October, 2003). 
9 This comes from interviews in 2005, and is consistent with research conducted in the 1980s (Komito 1985).

10 Despite the officials view of themselves as guardians of the public interest, continual problems with residential planning in Ireland show that the correct balance between experts, officials and citizens on these issues is not always obvious (see for instance Komito, 1983).

11 Ironically, perhaps the major beneficiaries from the protest were politicians. Each email received on the subject became a new email address to be added to a politician's database. By the end of the protest, some politicians had a substantial mailing list they could then use for future political campaigns.

12 See the final report 'E-consultation: evaluating appropriate technologies and processes for citizens' participation in public policy' (Fagan, et al., 2006, available at http://www.econsultation.org/files/ecrp_report.pdf).

\section{References}

Agre, P. E. 2002 'Real-Time Politics: The Internet and the Political Process', The Information Society 18: 311-31.

Agre, P. E. 2004 'The Practical Republic: social skills and the progress of citizenship', pp. 201-23 in A. Feenberg and D. Barney (eds) Community in the Digital Age: philosophy and practice. Lanham, MD: Rowman \& Littlefield.

Arnold, M., M. R. Gibbs, et al. 2003 'Intranets and local community: "yes, an intranet is all very well, but do we still get free beer and barbeque?", pp.185-204 in M. Huysman, E. Wenger and V. Wulf (eds), Communities and Technologies. Dordrecht: Kluwer.

Banton, M. (ed.) 1968 The Social Anthropology of Complex Societies. London: Tavistock.

Barrington, T. J. 1975 From Big Government to Local Government. Dublin: Institute of Public Administration.

Bell, C. and H. Newby 1971 Community Studies. London: George Allen \& Unwin.

Berkowitz, S. D. 1982 An introduction to structural analysis. Toronto: Butterworths.

Birdsall, W. F. 2000 'The Digital Divide in the Liberal State: a Canadian Perspective', First Monday 5 (12). http://firstmonday.org/issues/issue5_12/birdsall/index.html

Blondel, J., R. Sinnott, et al. 1998 People and Parliament in the European Union: Participation, Democracy, and Legitimacy. Oxford: Oxford University Press.

Boase, J., J. B. Horrigan, et al. 2006 The Strength of Internet Ties. Washington, D.C.: Pew Internet \& American Life Project. http://www.pewinternet.org/pdfs/PIP Internet ties.pdf

Castells, M. 1996 The rise of the network society. Oxford: Basil Blackwell.

Central Statistics Office 2003 Information Society Statistics - Ireland 2003. Dublin: Stationery Office.

Central Statistics Office 2006 Information Society and Telecommunications 2005. Dublin: Stationery Office.

Commission of the European Communities 2003 The Role of eGovernment for Europe's Future. Brussels: Commission of the European Communities. http://europa.eu.int/ information_society/eeurope/2005/doc/all_about/egov_communication_en.pdf

Docter, S. and W. H. Dutton 1998 'The First Amendment online: Santa Monica's public electronic network', pp. 125-51 in R. Tsagarousianou, D. Tambini and C. Bryan (eds), Cyberdemocracy: Technology, Cities and Civic Networks. London: Routledge. 
Etzioni, A. 2004 'On Virtual, Democratic Communities', pp. 225-38 in A. Feenberg and D. Barney (eds), Community in the Digital Age: Philosophy and Practice. Lanham, MD: Rowman \& Littlefield.

Fagan, G. Honor, D. R. Newman, P. McCusker, and M. Murray 2006 'E-consultation: evaluating appropriate technologies and processes for citizens' participation in public policy'. www.e-consultation.org, July 2006. http://www.e-consultation.org/files/ ecrp_report.pdf

Farr, J. 2004 'Social Capital: a conceptual history', Political Theory, 32 (1): 6-33.

Frankenberg, R. 1969 Communities in Britain: Social Life in Town and Country. Harmondsworth: Penguin.

Gluckman, M. 1971 Politics, Law and Ritual in Tribal Society. Oxford: Basil Blackwell.

Haase, T. and J. Pratschke 2003 Digital Divide: analysis of the uptake of information technology in the Dublin region. Dublin: Dublin Employment Pact.

Hampton, K. and B. Wellman 2000 'Examining community in the digital neighborhood: early results from Canada's wired suburb', pp. 194-208 in T. Ishida and K. K. Isbister (eds), Digital Cities: Technologies, Experiences and Future Prospects. Berlin: Springer.

Hampton, K. N. and B. Wellman 2002 'The not so global village of Netville', pp. 345-71 in B. Wellman and C. Haythornthwaite (eds), The Internet in Everyday Life. Oxford: Basil Blackwell.

Holland, P. W. and S. Leinhardt (eds) 1979 Perspectives on Social Network Research. New York: Academic Press.

Huysman, M., E. Wenger, et al. (eds) 2003 Communities and Technologies. Dordrecht: Kluwer.

International Telecommunication Union and M. Minges 2003 ITU Digital Access Index. Geneva: International Telecommunication Union. http://www.itu.int/newsarchive/ press_releases $/ 2003 / 30 . \mathrm{html}$

Kavanaugh, A. L., P. L. Isenhour, et al. 2005 'Information Technology in Support of Public Deliberation', in P. v. d. Besselaar, G. de Michelis, J. Preece, et al. Communities and Technologies 2005. Dordrecht: Springer.

Kavanaugh, A. L. and S. J. Patterson 2002 'The impact of community computer networks on social capital and community involvement in Blacksburg', pp. 325-44 in B. Wellman and C. Haythornthwaite (eds) The Internet in Everyday Life. Oxford: Blackwell.

Kavanaugh, A. L., D. D. Reese, et al. 2003 'Weak ties in networked communities', pp. 265-86 in M. Huysman, E. Wenger and V. Wulf (eds), Communities and Technologies. Dordrecht: Kluwer.

Kitchin, R. 1998 Cyperspace: the World in the Wires. Chichester: Wiley.

Kolko, B. and E. Reid 1998 'Dissolution and fragmentation: problems in on-line communities', pp. 212-29 in S. G. Jones (ed.), Cybersociety 2.0: Revisiting ComputerMediated Communication and Community. Thousand Oaks, CA: Sage.

Kollock, P. 1999 'The economies of online cooperation: gifts and public goods in cyberspace', pp. 220-39 in M. A. Smith and P. Kollock (eds), Communities in Cyberspace. London: Routledge.

Komito, L. 1983 'Development plan rezonings: the political pressures', pp. 293-302 in J. Blackwell and F. Convery (eds), Promise and Performance: Irish Environmental Policies Analysed. Dublin: Resource and Environmental Policy Centre, University College Dublin. 
Komito, L. 1985 Politics and Clientelism in Urban Ireland: Information, Reputation, and Brokerage. PhD University of Pennsylvania. Ann Arbor, MI: UMI no. AAD86-03660.

Komito, L. 1998 'The Net as a foraging society: flexible communities', The Information Society 14 (2): 97-106.

Komito, L. 2001 'Electronic community in the Information Society: paradise, mirage or malaise?', Journal of Documentation 57 (1): 115-29.

Komito, L. 2004 The Information Revolution and Ireland: Prospects and Challenges. Dublin: UCD Press.

Lenhart, A., J. Horrigan, et al. 2003 The Ever-Shifting Internet Population: A New Look at Internet Access and the Digital Divide. The Pew Internet \& American Life Project. http://www.pewinternet.org/pdfs/PIP_Shifting_Net_Pop_Report.pdf

Macintosh, A. 2004 'Characterising E-Participation in Policy-Making'. 37th Hawaii International Conference on System Sciences.

Mauss, M. 1967 The Gift: Forms and Functions of Exchange in Archaic Societies. New York: W. W. Norton.

McCaffrey, C. 2003 The Digital Divide in the EU: National Policies and Access to ICTs in the Member States. Dublin: Oscail - National Distance Education Centre, Dublin City University. http://www.oscail.ie/caffrey.pdf

McQuillan, H. 2000 Eircom Ennis information age town: a connected community. Eircom Ennis Information Age Town Ltd. http://www.eiat.ie/multimedia/evaluation_report.pdf

McQuillan, H. 2002 'Ennis Information Age Town: Virtuality Rooted in Reality', pp.139-51 in M. Tanabe, P. v. d. Besselaar and T. Ishida (eds), Digital Cities II: Computational and Sociological Approaches. Berlin: Springer.

Mitchell, J. C. (ed.) 1969 Social Networks in Urban Situations. Manchester: Manchester University Press.

National Telecommunications and Information Administration 2002 A Nation Online: How Americans are expanding their use of the Internet. Washington, D.C.: United States Department of Commerce.

Newton, K. 1999 'Social capital and democracy in modern Europe', pp. 3-24 in J. W. van Deth, M. Maraffi, K. Newton, et. al (eds) Social Capital and European Democracy. London: Routledge.

Nie, N. H. 2001 'Sociability, interpersonal relations and the internet: reconciling conflicting findings', American Behavioral Scientist, 45 (3): 420-35.

Nie, N. H., D. S. Hillygus, et al. 2002 'Internet Use, Interpersonal Relations, and Sociability: a time diary study', pp. $215-43$ in B. Wellman and C. Haythornthwaite (eds), The Internet in Everyday Life. Oxford: Blackwell.

O'Donnell, S. 2001 Towards an inclusive Information Society in Europe: the role of voluntary organisations. Information Society Technologies Research Programme, European Commission.

O'Donnell, S., H. McQuillan, et al. 2003 eInclusion: Expanding the Information Society in Ireland. Dublin: Information Society Commission.

O'Donnell, S. and G. Ramaioli 2004 Sustaining an Online Information Network for NonProfit Organisations: The Case of Community Exchange National Research Council of Canada. http://iti-iit.cnrc-nrc.gc.ca/publications/nrc-47427_e.html

O'Donnell, S., B. Trench, et al. 1998 Weak connections: final report of the research project The Voluntary Sector in the Information Age. Dublin: Dublin City University. 
Olson, M. 1965 The Logic of Collective Action: Public Goods and the Theory of Groups. Cambridge, MA: Harvard University Press.

Organisation for Economic Co-operation and Development 2003 Promise and Problems of E-Democracy: Challenges of Online Citizen Engagement. Paris: Organisation for Economic Co-operation and Development.

PEW Internet and American Life Project 2001 'Online communities: networks that nurture long-distance relationships and local ties', http://www.pewinternet.org.

Pigg, K. E. and L. D. Crank 2004 'Building Community Social Capital: The Potential and Promise of Information and Communications Technologies', Journal of Community Informatics 1 (1): 58-73.

Polanyi, K. 1957 The Great Transformation. Boston: Beacon Press.

Portes, A. and P. Landolt 1996 'Unsolved Mysteries: The Tocqueville Files II. The Downside of Social Capital', The American Prospect 7, 26.

Power Inquiry 2006 Power to the People: The Report of Power: An Independent Inquiry into Britain's Democracy. http://www.powerinquiry.org/report/documents/Powertothe People_002.pdf

Putnam, R. D. 2000 Bowling Alone: America’s Declining Social Capital. New York: Simon \& Schuster.

Putnam, R. D., R. Leonardi, et al. 1993 Making Democracy Work: Civic Traditions in Modern Italy. Princeton, NJ: Princeton University Press.

Rheingold, H. 1994 The Virtual Community: Finding Connection in a Computerised World. London: Secker \& Warburg.

Robins, K. and F. Webster 1986 Information Society: Post-Industrial Society or Capitalist Control. Norwood, NJ: Ablex.

Robins, K. and F. Webster 1987 'Information as capital: a critique of Daniel Bell', pp. 95-117 in J. D. Slack and F. Fejes (eds), The Ideology of the Information Age. Norwood, NJ: Ablex.

Roche, D. 1982 Local Government in Ireland. Dublin: Institute of Public Administration.

Rothstein, B. 2003 'Social Capital, Economic Growth and Quality of Government: the causal mechanism', New Political Economy 8 (1): 49-73.

Sahlins, M. 1972 Stone Age Economics. Chicago: Aldine.

Sciadas, G. 2002 Monitoring the Digital Divide. UNESCO, Orbicom-CIDA Project Report. http://www.orbicom.uqam.ca/projects/ddi2002/ddi2002.pdf

Smith, M. A. and P. Kollock (eds) 1999 Communities in Cyberspace. London: Routledge.

Tsagarousianou, R., D. Tambini, et al. (eds) 1998 Cyberdemocracy: Technology, Cities and Civic Networks. London: Routledge.

Van der Eijk, C. and M. N. Franklin 1996 Choosing Europe?: The European Electorate and National Politics in the Face of Union. Ann Arbor, MI: University of Michigan Press.

Wasserman, S. and K. Faust 1994 Social Network Analysis: Methods and Applications. Cambridge: Cambridge University Press.

Watson, N. 1997 'Why we argue about virtual community: a case study of the phish.net fan community', pp. $102-32$ in S.G. Jones (ed.) Virtual Culture: Identity and Communication in Cybersociety. London: Sage.

Wellman, B. 1988 'The community question re-evaluated', pp. 81-107 in M. P. Smith (ed.) Power, Community and the City. New Brunswick, NJ: Transaction.

Wellman, B 1996 ‘Are personal communities local? A Dumptarian reconsideration', Social Networks 18: 347-54. 
Wellman, B (ed.) 1999 Networks in the Global Village: Life in Contemporary Communities. Boulder, CO: Westview.

Wellman, B. and S. D. Berkowitz 1988 Social Structures: A Network Approach. Cambridge: Cambridge University Press.

Wellman, B. and C. A. Haythornthwaite (eds) 2002 The Internet in Everyday Life. Malden, MA: Blackwell.

Wellman, B., A. Quan-Haase, et al. 2003 'The Social Affordances of the Internet for Networked Individualism', Journal of Computer Mediated Communication 8 (3). http://www.ascusc.org/jcmc/vol8/issue3/ 